\title{
Pola Komunikasi Keluarga dalam Pembentukan \\ Kepribadian Anak
}

\section{St. Rahmah}

\section{UIN Antasari Banjarmasin}

\begin{abstract}
Humans are social creatures who need a good relationship with other people, and have the urge to relate to other people and other impulses such as curiosity, self-actualization, and so on, it will be discarded by communicating with each other. Because humans can always develop and be able to carry out community life, of course, with communication, which can be done at any time, when, by whom and with anyone. Likewise with communication for a child in a family who has work to be used in the community. Parents in a family become a figure for children in the form of the same thing, behavior, speech words formed by parents of parents. The key pattern of communication in the family that is built will affect the parenting style of the children. With good communication patterns will create good parenting patterns, the formation of children in the family form as an effort of parents for the virtue of behaving that must be done early is the basis of education. The formation of awareness as the basis of education is a manifestation of the formation of a child's personality.

Keywords: Family, Child, Personality, Pattern of communication.
\end{abstract}

\section{Pendahuluan}

Kehadiran seorang anak disisi orang tua tidak harus membuat orang tua terbuai dengan kebanggaan. Kebanggaan itu mungkin saja membuat orang terlena, karena tugas lain yakni mendidik anak adalah tanggung jawab orang tua, apapun usaha yang dilakukan oleh orang 
tua dalam mendidik anak mereka berharap bahwa anaknya mempunyai kepribadian yang baik.

Setiap orang tua mengharapkan agar anak-anaknya membahagiakannya di dunia maupun akhirat, namun hal ini tentu tidak semudah membalikkan telapak tangan. Karena orang tua harus bekerja keras dan terus berdoa kepada Allah Swt agar anak tersebut dapat menjadi pribadi yang diinginkan.

Kepribadian merupakan ciri-ciri dan sifat-sifat yang khas yang mewakili sikap atau tabiat dari diri seseorang yang bersumber dari pola-pola pemikiran dan perasaan, konsep diri yang diterima dari lingkungan, misalnya, keluarga pada masa kecil, dan juga bawaan seseorang sejak lahir. (Sjarkawi, 2006:11)

Dengan melihat dan belajar dari orang-orang yang berada disekitarnya kepribadian seorang anak akan terbentuk, dan keluargalah orang yang terdekat bagi anak yang mempunyai pengaruh sangat besar. Berbagai macam tingkah laku orang tua yang baik maupun buruk akan dicontoh oleh anak.

Faktor yang sangat penting diperhatikan dalam pendidikan anak adalah komunikasi, karena komunikasi merupakan dasar dari seluruh hubungan antar manusia, baik yang terjadi antara perorangan, kelompok maupun organisasi tidak mungkin terjadi tanpa adanya sebuah komunikasi.

Eduard Depari, Ph. D, mengatakan bahwa komunikasi merupakan sebuah proses penyampaian pesan, gagasan dan harapan yang disampaikan melalui lambang tertentu yang mengandung arti, dan dilakukan oleh penyampai pesan (sumber, komunikator) yang ditujukan kepada penerima pesan (receiver, komunikan, audience) dengan tujuan untuk mencapai suatu kebersamaan (commonnees), (A.W. Widjaja: 2010: 2). 
Komunikasi dapa disimpulkan merupakan hubungan kontak antar dan antara manusia, baik individu maupun kelompok, karena dalam kehidupan sehari-hari disadari atau tidak komunikasi adalah bagian dari kehidupan manusia. Bahkan sejak manusia dilahirkan sudah berkomunikasi dengan lingkungannya. Gerak dan tangis yang pertama pada saat ia dilahirkan merupakan suatu pertanda adanya komunikasi. (A.W. Widjaja: 2010: 1)

Terlebih lagi ditekankan oleh Deddy Mulyana bahwa tanpa melibatkan diri dalam komunikasi seseorang tidak akan mengetahui bagaimana makan, minum, berbicara sebagai manusia dan memperlakukan manusia lain secara beradab, karena cara-cara berperilaku harus dipelajari lewat pengasuhan keluarga dan pergaulan dengan orang lain yang intinya adalah komunikasi, bahkan lebih jauh menurut beliau bahwa orang yang tidak pernah berkomunikasi dengan manusia dapat dipastikan akan tersesat, karena ia tidak berkesempatan untuk menata dirinya dalam suatu lingkungan sosial.(Deddy Mulyana: 2000: 5)

Komunikasi di dalam sebuah keluarga adalah penyampaian pesan dari ayah, ibu, orang tua, anak, suami, isteri, mertua, kakek, nenek maupun sebaliknya sebagai penerima pesan. Pesan yang disampaikan dalam komunikasi tersebut dapat berupa informasi, nasehat, petunjuk, pengarahan, maupun meminta bantuan. Komunikasi yang terjadi dalam keluarga merupakan suatu komunikasi yang unik, dan komunikasi yang terjadi didalam keluarga tentu akan melibatkan paling sedikit dua orang yang mempunyai sifat, nilai-nilai, pendapat, sikap, pikiran dan perilaku yang khas dan berbeda-beda.

Komunikasi keluarga adalah komunikasi yang berlangsung dalam sebuah keluarga, yakni cara seorang anggota keluarga untuk 
berhubungan dengan anggota keluarga lainnya, sebagai tempat untuk menanamkan dan mengembangkan nilai-nilai yang diperlukan sebagai pegangan hidup. Keluarga merupakan tempat pertama komunikasi diajarkan, dan di dalam keluargalah kita pertama kali belajar bagaimana membentuk, membina, dan mengakhiri sebuah hubungan, berekspresi, berdebat, dan menunjukkan kasih sayang, disamping suasana kekeluargaan dan kelancaran berkomunikasi antara anggota keluarga dapat tercapai apabila setiap anggota keluarga menyadari dan menjalankan tugas dan kewajiban masing-masing sambil menikmati haknya sebagai anggota keluarga, karena apa yang terjadi jika sebuah pola komunikasi keluarga tidak terjadi secara harmonis tentu akan mempengaruhi perkembangan anak.

Komunikasi keluarga tidak dapat disamakan dengan komunikasi antar anggota kelompok biasa. Komunikasi yang terjadi dalam suatu keluarga tidak sama dengan komunikasi keluarga yang lain. Setiap keluarga mempunyai pola komunikasi tersendiri. Hubungan orang tua dengan anak senantiasa dipengaruhi dan ditentukan oleh sikap orang tua itu sendiri, baik sikap yang berhubungan dengan afeksi maupun dominasi, karena pada kenyataannya ada orang tua yang mendominasi, yang memanjakan, acuh tak acuh dan ada orang tua yang akrab, terbuka dan bersahabat dengan anak-anaknya.

Keluarga merupakan ujung tombak dalam pembentukan pribadi anak karena keluarga mempunyai peranan yang paling penting dalam persoalan pendidikan anak, dan keluarga merupakan tempat tumbuh kembang anak mulai dari lahir hingga dewasa. Oleh sebab itulah pendidikan dalam keluarga harus menjadi perhatian yang utama.

Orang tua yang berkomunikasi secara baik, bisa dianggap teman oleh anak dan akan menjadikan kehidupan yang hangat dalam 
keluarga, sehingga antara orang tua dan anak mempunyai keterbukaan dan saling memberi.Disamping itu anak diberi kebebasan untuk mengemukakan berbagai pendapat, gagasan, keinginan, perasaan, serta kebebasan untuk menanggapi pendapat orang lain. Anak-anak yang hidup dengan pola komunikasi orang tua yang efektif akan menghasilkan kepribadian anak yang dapat mengontrol diri, anak yang mandiri, mempunyai hubungan baik dengan teman, dan mampu menghadapi berbagai persoalan dalam kehidupannya.

Pola komunikasi yang baik untuk pembentukan kepribadian anak yang baik adalah pola komunikasi orang tua yang memprioritaskan kepentingan anak dan interakasi

yang terjalin tidak hanya dari orang tua ke anak, juga antara anak kepada orang tua dan

anak dengan anak, orang tua juga harus mengendalikan anak, sehingga anak yang juga hidup dalam masyarakat, bergaul dengan lingkungan dan tentunya anak mendapatkan pengaruh-pengaruh dari luar yang mungkin dapat merusak kepribadian anak, akan dapat dikendalikan oleh orang tua dengan menerapkan sikap-sikap yang baik dalam keluarga

serta contoh atau tauladan dari orang tuanya.

Dengan demikian membentuk kepribadian seorang anak sangat dipengaruhi oleh pola komunikasi yang digunakan orang tua dalam keluarga, dan seyogianya setiap orang tua untuk mengetahui dan memahami bagaimanakah cara berkomunikasi yang baik dengan anak sehingga terbentuklah hubungan yang baik antara orang tua dan anak di dalam sebuah keluarga. 


\section{Keluarga Sebagai Agen Sosialisasi}

Keluarga adalah dimana tempat kita berlindung dari segala ancaman dan mara bahaya yang akan mengganggu kelangsungan hidup kita.peran keluarga sangat penting dalam perkembangan hidup keturunannya, ketika peran keluarga tidak berfungsi maka sosialisasidalam keluarga tidak berjalan sebagaimana mestinya, dan Agen sosialisasi yang utama adalah keluarga, kelompok bermain, sekolah, lingkungan dan media massa.

Seorang anak yang baru lahir akan mengalami proses sosialisasi yang pertama kali di dalam keluarga. Seorang anak akan mulai mengenal seluruh anggota keluarganya, yaitu ayah, ibu, dan saudaranya sampai anak mengenal dirinya sendiri serta mentaati norma-norma yang berlaku dalam keluarganya, sehingga diharapkan akan tercipta sebuah keluarga yang harmonis, karena bagaimanapun sebuah keluarga adalah institusi yang paling besar pengaruhnya terhadap proses sosialisasi manusia.

Sebagai kesatuan yang terkecil dalam masyarakat kedudukan keluarga berada pada tempat yang fundamental, dan memiliki peran yang sangat besar mempengaruhi kehidupan seorang anak, Sebuah keluarga yang tidak berhasil memberi kasih sayang dan perhatian kepada anak akan menciptakan kebencian, rasa tidak aman dan tindak kekerasan kepada anak-anaknya. Begitu pula dengan keluarga yang tidak dapat menciptakan suasana pendidikan yang seharusnya tentu akan menyebabkan anak-anak tidak berada dijalan yang semestinya sesuai aturan atau norma yang berlaku.

Salah satu hal yang perlu dipertimbangkan bahwa corak hubungan orang tua dengan anak akan menentukan proses sosialisasi serta perkembangan kepribadian seorang anak, yaitu pola menerimamenolak, memakai-melepaskan, dan demokrasi-otokrasi. 


\section{Pola menerima-menolak}

Pola menerima-menolak ini didasarkan pada tingkat kemesraan orang tua terhadap anak. Anak yang berada dalam keluarga penganut pola menolak akan melahirkan sikap menantang kekuasaan dan selalu bersikap menaruh kecurigaan kepada orang lain Anak sudah tidak takut lagi terhadap berbagai hukuman karena sudah terlalu sering mendapat hukuman dari orang tuanya.

2. Pola memiliki-melepaskan

Pola ini beranjak dari sikap orang tua yang over protektif sampai mengabaikan anaknya sama sekali. Sehingga anak akan cenderung berwatak tidak patuh, tidak dapat menahan emosi, dan menuntut orang lain secara berlebihan, pemalu, cemas, dan ragu-ragu.

3. Pola demokrasi-otokrasi

Pada pola otokrasi, orang tua bertindak sebagai diktator terhadap anak, dengan kata lain merupakan pola asuh yang sangat keras karena orang tua tidak takut untuk meghukum anaknya baik secara mental maupun fisik ketika anak tidak melakukan apa yang diperintahkan. Disamping itu sisi positifnya dari pola ini bahwa sikap orang tua yang otoriter akan menunjang perkembangan sikap kemandirian dan tanggung jawab sosial. Sedangkan pola demokrasi merupakan jenis pola dimana anak diberi peluang untuk menyampaikan pendapat, gagasan, maupun keinginannya. (J. Dwi Narwoko: 2004: 73)

Orang tua yang otoriter cenderung memaksa anaknya untuk mengikuti apa yang mereka inginkan. Biasanya mereka membuat berbagai aturan yang harus dipatuhi dan memberi hukuman jika anak melanggar aturan yang dibuat. Pada umumnya orang tua seperti ini tidak ramah kepada anak, cenderung mengambil jarak terhadap anak, dan sering memberikan hukuman fisik, misalnya 
memukul anak. Dengan pola ini sering anak sering merasa tertekan dan tidak percaya kepada orang tuanya, dan anak akan tumbuh sebagai orang yang kurang percaya diri, agresif, dan bersikap mengganggu teman-temannya.

Sedangkan orang tua yang demokratis akan memerhatikan kebutuhan anak, menghargai kepentingan anak, dan mengarahkan anak untuk mengikuti aturan sosial. Orang tua menghargai pendapat, keputusan, minat, kepribadian, dan kemampuan anak dalam menyelesaikan atau menghadapi permasalahan. Orang tua menetapkan aturan, memberikan batasan-batasan, serta menjelaskan kenapa anak tidak boleh melakukan suatu tindakan yang dilarang. Dengan pola ini anak akan tumbuh menjadi pribadi yang percaya diri, mandiri, dapat mengontrol diri, berani, dan menghargai pendapat orang lain.

Dalam keluarga orang tua bertanggungjawab untuk memberikan pendidikan kepada anak-anaknya dengan pendidikan yang baik berdasarkan nilai-nilai akhlak dan spiritual yang luhur, tetapi realitasnya tidak semua orang tua dapat melakukannya, dengan demikian orang tua sebagai lingkungan pertama dan utama dimana anak berinteraksi sebagai lembaga pendidikan yang tertua, artinya disinilah dimulai suatu proses pendidikan.

\section{Pola Komunikasi Keluarga dalam Pembentukan Kepribadian Anak}

Hubungan kontak antar dan antara manusia, baik dilakukan secara individu maupun kelompok disebut komunikasi. Disadari atau tidak dalam kehidupan sehari-hari disadari komunikasi merupakan suatu bagian dari kehidupan manusia. Bahkan sejak dilahirkan, manusia sudah berkomunikasi dengan lingkungannya, seperti gerak 
dan tangis yang pertama terjadi pada saat ia dilahirkan adalah suatu tanda berlangsungnya sebuah komunikasi. (A. W. Widjaja: 2010: 1).

Komunikasi merupakan suatu dasar dan kunci seseorang dalam menjalankan tugasnya, komunikasi merupakan suatu proses perawatan untuk menjalankan dan menciptakan hubungan antara anak dan orang tua, komunikasi tampaknya sederhana tetapi untuk menjadikan suatu komunikasi yang berguna dan efektif membutuhkan usaha dan keterampilan serta kemampuan dalam bidang tersebut.

Komunikasi merupakan faktor yang penting bagi perkembangan diri seorang anak, karena ketika tidak adanya komunikasi di dalam sebuah keluarga akan dapat menyebabkan sesuatu hal yang tidak diinginkan, seperti timbulnya perilaku yang tidak diinginkan pada anak yang menyalahi norma agama maupun norma yang berlaku di dalam masyarakat, karena bermacam-macam persoalan yang dialami oleh seorang anak, dapat menyebabkan sebagian anak mengalami depresi, kegoncangan nilai dan perilaku yang tidak terpuji, termasuk kurang efektifnya komunikasi dalam keluarga sebagai akibat dari kegagalan orang tua dalam menurunkan nilai-nilai rohani atau nilai moral kepada anaknya, karenanya komunikasi merupakan dasar dari seluruh interaksi antar manusia. Dan segala sesuatu yang diperbuat anak akan mempengaruhi keluarganya begitu juga sebaliknya, keluarga memberikan dasar pembentukan tingkah laku, watak, moral dan pendidikan kepada anak.

Lebih jelas dikemukakan Theo Riyanto, dalam suatu komunikasi sangat penting diperhatikan adalah kemampuan mendengarkan dengan penuh simpati. Mendengarkan dengan penuh simpati itu sendiri ditandai dengan: (1) Kepekaan akan perasaan yang menyertai pesan yang disampaikan; (2) Mendengarkan dengan penuh perhatian; 
(3) Tidak memotong pembicaraan dan memberikan komentar ditengahtengah; (4) Perhatian terhadap, "dunia" pembicara; (5) Sendiri tidak penting, yang penting adalah pembicara. (Theo Riyanto: 2002:230)

Komunikasi di dalam keluarga tidak terlepas dari peran orang tua yang sangat dominan. Komunikasi akan berjalan dengan baik dan lancar apabila orang tua memiliki kepercayaan dimata anaknya.

Komunikasi yang dilakukan antara orang tua dengan anak secara intens akan sangat sangat membantu keefektifan hubungan psikologis antara orang tua dengan anak, karena pada dasarmya pribadi manusia itu mudah atau dapat dipengaruhi oleh sesuatu, karena itu dengan adanya usaha membentuk pribadi, membentuk watak atau mendidik watak anak dengan kata lain berusaha untuk memperbaiki kehidupan anak yang nampak kurang baik, sehingga menjadi baik.

Keluarga memiliki peran sangat penting dalam pembentukan kepribadian seorang anak, karena dari sejak kecil anak hidup, tumbuh dan berkembang didalam keluarga. Sebagian orang tua ada yang tidak memperhatikan perkembangan anak-anaknya. Orang tua selalu disibukkan oleh aktivitasnya sendiri sedangkan anak sibuk dengan teman sepermainannya. Oleh karena itu, banyak disuatu keluarga yang tidak saling berkomunikasi antara satu sama lain, dan orang tua tidak mengetahui dengan perkembangan anak-anaknya dan terlebih lagi dengan masalah-masalah apa yang dihadapi anak, sehingga sering ditemui anak-anak yang tidak diperhatikan orang tuanya dan berkembang dengan lingkungan keluarga yang tidak harmonis memiliki pribadi yang tidak baik.

Menurut Mcleod dan Chaffee dalam Limbong (1966), mengemukakan bahwa komunikasi keluarga adalah sebuah komunikasi yang berorientasi sosial yaitu suatu hubungan yang 
menekankan hubungan baik, dan komunikasi yang berorientasi konsep yaitu komunikasi yang mendorong anak-anak untuk mengembangkan pandangan dan mempertimbangkan masalah dari berbagai segi. McLeod dan Chaffee membagi komunikasi keluarga ini ke dalam empat pola, yaitu: (1) Komunikasi keluarga dengan pola Laissez-faire, komunikasi ini ditandai dengan rendahnya komunikasi yang berorientasi konsep, artinya seorang anak tidak diarahkan untuk mengembangkan diri secara mandiri, dan juga rendah dalam komunikasi yang berorientasi sosial. Artinya anak tidak membina keharmonisan hubungan dengan bentuk interaksi dengan orang tua. Anak maupun orang tua kurang atau tidak memahami objek komunikasi, sehingga dapat menimbulkan komunikasi yang salah. (2) Komunikasi keluarga dengan pola Protektif, Komunikasi dengan pola protektif yang digunakan orang tua dalam membentuk kepribadian seorang anak, yakni dimana orang tua yang tidak memberi batasan yang dalam terhadap perilaku seorang anak. Orang tua dalam pola protektif hanya memberi batasan pada anak yang dominan saja. MIsalnya, anak perempuan tidak boleh pulang larut dan tidak boleh menginap di rumah teman. Anak-anak yang berasal dari keluarga yang menggunakan pola protektif dalam berkomunikasi mudah dibujuk, karena mereka tidak belajar bagaimana membela atau mempertahankan pendapat sendiri. (3) Komunikasi keluarga dengan pola Pluralistik, merupakan bentuk komunikasi keluarga yang menjalankan model komunikasi yang terbuka dalam membahas ideide dengan semua anggota keluarga, menghormati minat anggota lain dan saling mendukung. (4) Komunikasi keluarga dengan pola Konsensual, Keluarga yang menerapkan pola ini menjunjung tinggi adanya munsyawarah mufakat dalam pengambilan keputusan. Bentuk komunikasi keluarga ini menekankan komunikasi berorientasi 
sosial maupun yang berorientasi konsep. Semua anggota keluarga diberi kempatan yang sama untuk mengemukakan ide dari berbagai sudut pandang, tanpa mengganggu struktur kekuatan keluarga.

Pola komunikasi sebagai suatu sistem penyampaian pesan melalui lambang tertentu, mengandung arti, dan pengoperan perangsang untuk mengubah tingkah laku individu lain. Sehingga penerapan sebuah pola komunikasi di dalam keluarga sebagai bentuk interaksi antara orang tua dengan anak maupun antar anggota keluarga memiliki implikasi terhadap proses perkembangan emosi anak ataupun anggota keluarga itu sendiri, dan di dalam proses komunikasi tersebut, setiap anggota keluarga akan belajar mengenal dirinya serta memahami perasaannya sendiri maupun perasaan orang lain.

Komunikasi yang berlangsung secara timbal balik dan silih berganti dalam keluarga, baik dari orang tua kepada anak ataupun dari anak kepada orang tua, atau dari anak kepada anak. Dengan adanya pola komunikasi yang baik maka akan terciptanya pola asuh yang baik pula. Dengan demikian Kegiatan pendidikan anak akan berhasil dengan baik jika pola komunikasi yang tercipta di lembari dengan cinta dan kasih sayang dengan memposisikan anak sebagai subjek yang harus dibina, dibimbing, dan dididik, dan bukan hanya sebagai objek semata.

Menurut Syaiful Bahri bahwa pola komunikasi yang sering terjadi antara orang tua dengan anak dalam kehidupan keluarga adalah berkisar diseputar tiga (3) pola komunikasi, antara lain model stimulus-respon, model ABX, dan model interaksional. (Syaiful Bahri Djamarah: 2004: 39) 


\section{Model Stimulus-Respon}

Pola komunikasi yang lumrah terjadi dalam keluarga adalah model stimulus-respon ( $\mathrm{S}-\mathrm{R}$ ). Pola ini menunjukkan bahwa komunikasi sebagai suatu proses aksi-reaksi yang sangat sederhana. Pola S - R mengasumsikan bahwa kata-kata verbal (lisan-tulisan), isyarat-isyarat non verbal, gambar-gambar, dan tindakan-tindakan tertentu akan merangsang orang lain untuk memberikan respon dengan cara tertentu. Oleh karena itulah proses ini dapat bersifat timbal balik dan mempunyai banyak efek, dan setiap efek dapat mengubah tindakan komunikasi berikutnya. Dalam kehidupan seharihari pola komunikasi ini sering terjadi ketika orang tua memberikan isyarat verbal, nonverbal, gambar-gambar atau tindakan-tindakan tertentu untuk merangsang anak. Misalnya pada saat orang tua melambaikan tangannya anak pun membalasnya dengan lambaian tangan.

Dengan demikian dalam pola komunikasi model $S-R$ di sini orang tua dituntut lebih proaktif dan kreatif untuk memberikan rangsangan kepada anak sehingga kepekaan anak atas rangsangan yang diberikan semakin membaik.

\section{Model ABX}

Model ABX dikemukakan oleh Newcomb dari perspektif psikologi sosial. Newcomb menggambarkan bahwa seseorang (A) menyampaikan informasi kepada seseorang lainnya (B) mengenai sesuatu (X). Menurut Mulyana, bila A dan B mempunyai sikap positif terhadap satu sama lain dan terhadap X (orang, gagasan atau benda) hubungan itu merupakan simetri. Dalam konteks ini, Mulyana menegaskan bahwa bila A dan B saling membenci dan salah satu menyukai X, sedangkan

yang lainnya tidak, hubungan itu juga merupakan simetri. Akan tetapi 
bila A dan B saling menyukai, namun mereka tidak sependapat mengenai $\mathrm{X}$ atau bila mereka saling membenci, namun sependapat mengenai $\mathrm{X}$, maka hubungan mereka bukan simetri. (Deddy Mulyana: 2000: 5)

Dalam keluarga, suami-isteri sering membicarakan anaknya, apakah itu terkait dengan persoalan sikap dan perilaku anak, pergaulan anak, masalah sandang atau pangan anak, ataupun masalah pendidikan anak. Ketika membicarakan kedua orang tua itu berlangsung, anak sama sekali tidak terlibat dalam pembicaraan itu. Sebagai objek yang dibicarakan, anak hanya menunggu hasilnya dan mungkin melaksanakannya sebatas kemanpuannya.

\section{Model Interaksional}

Dalam komunikasi model interaksional, Interaksi yang terjadi antar individu tidak sepihak, tetapi antar individu saling aktif, refktif, dan kreatif dalam memaknai dan menafsirkan pesan yang dikomunikasikan. Semakin cepat memberikan pemaknaan dan penafsiran terhadap pesan yang disampaikan maka akan berdampak semakin lancar kegiatan komunikasi tersebut.

Interaksi berlangsung secara timbal balik dan dinamis, pandangan antara pembicara dengan lawan bicara yang positif menciptakan komunikasi yang harmonis. Komunikasi model interaksional inilah seharusnya yang terbentuk dalam keluarga, karena dari pola komunikasi model interaksional itulah lahirnya bermacam-macam bentuk interaksi sosial dalam keluarga, baik secara individual maupun kelompok melahirkan hubungan dengan intensitas yang bervariasi antara sepasang suami-isteri, antara ayah, ibu, dan anak dalam keluarga. 
Untuk menciptakan kepribadian yang kuat dan jiwa yang baik pada anak di dalam keluarga, diperlukan terciptanya suasana keluarga yang harmonis dan dinamis. Hal tersebut dapat tercipta jika terbangun koordinasi dan komunikasi dua arah yang kuat antara orang tua dengan anak. Pembentukan kepribadian anak tersebut akan tercapai apabila adanya komunikasi yang baik antara orang tua dan anaknya. Setiap orang tua tentunya menginginkan anaknya memiliki kepribadian yang baik, namun seiring pertumbuhan anak juga tidak terlepas dari pengaruh lingkungan sekitarnya, tentu anak tersebut seringkali mendapatkan hal-hal yang dapat mempengaruhi pribadinya. Misalnya ketika seorang anak berteman dengan teman yang agak keras dan kasar dalam kesehariannya, ataupun ketika seorang anak bergaul dengan kehidupan anak-anak yang nakal. Tentunya hal seperti ini dapat mempengaruhi pembentukan kepribadian anak tersebut.

Fungsi sosialisasi dan komunikasi dalam keluarga sebagai proses penanaman nilai dan norma yang dijunjung tinggi oleh masyarakat kepada anggota keluarga agar mereka mampu berperan menjadi orang dewasa dikemudian hari, sesuai patokan yang berlaku dalam masyarakat. Nilai yang ditanamkan merupakan hal dasar yang fundamental seperti antara lain tentang nilai kejujuran, keadilan, budi pekerti, prndidikan dan kesehatan. Untuk menegakkan nilai-nilai itu diperlukan sejumlah norma atau aturan berperilaku sebagai patokan bagi anggota masyarakat sehingga dapat mengindahkan nilai dimaksud dalam kehidupan bersama atau masyarakat. Misalnya untuk menegakkan nilai kejujuran sebagai prinsif dasar, orang tidak boleh berbohong, untuk menegakkan nilai keadilan diperlukan aturan agar tidak memihak, untuk menegakkan budi pekerti bersikap sopan tidak sombong dan untuk menegakkan nilai kesehatan ada aturan 
makan dan tidur yang teratur serta hidup bersih. Suasana kekeluargaan dan kelancaran berkomunikasi antara anggota keluarga dapat tercapai apabila setiap anggota keluarga menyadari dan menjalankan tugas dan kewajiban masing-masing sambil menikmati haknya sebagai anggota keluarga.

Kepribadian positif pada seorang anak dapat dilihat dari aktualisasi diri mereka berupa perilaku sebagai berikut: (Syarkawi: 2006: 35)

\section{Mandiri}

Kemandirian adalah sikap (perilaku) dan mental yang memungkinkan seseorang untuk bertindak bebas, benar, dan bermanfaat; berusaha melakukan segala sesuatu dengan jujur dan benar atas dorongan dirinya sendiri dan kemampuan mengatur diri sendiri, sesuai dengan hak dan kewajibannya, sehingga dapat menyelesaikan masalah-masalah yang dihadapinya; serta bertanggung jawab terhadap segala keputusan yang telah diambilnya melalui berbagai pertimbangan sebelumnya.

2. Disiplin

Kedisiplinan merupakan sikap mental untuk melakukan hal-hal yang seharusnya pada saat yang tepat dan benar-benar menghargai waktu. Sebelum seorang anak mendisiplinkan dirinya sendiri, ia terlebih dahulu harus didisiplinkan oleh orang tuanya.

3. Percaya Diri

Percaya diri merupakan suatu perasaan yang teguh pada pendirian, tabah dalam menghadapi masalah, kreatif dalam mencari jalan keluar dan ambisi dalam mencapai sesuatu.

4. Terbuka

Keterbukaan meliputi perilaku seorang individu yang sangat mudah untuk mengemukakan isi hati dan pendapatnya dan senang 
berbicara. Komunikasi yang efektif antara orang tua dan anak sangat besar pengaruhnya dalam menumbuhkan sikap keterbukaan pada diri anak.

5. Kreatif

Menurut Maslow, anak-anak pada dasarnya kreatif. Maslow mengartikan kreatif sebagai bentuk tindakan yang asli, naif, dan spontan sebagaimana yang sering dijumpai pada anak-anak yang polos dan jujur.

6. Bertanggungjawab

Bertanggungjawab adalah Sikap dan perilaku seseorang untuk melaksanakan tugas dan kewajibannya, yang seharusnya dia lakukan, terhadap diri sendiri, masyarakat, lingkungan, negara dan Allah Swt.

Maslow menyatakan orang yang bertanggungjawab akan melaksanakan kewajibannya dengan sungguh-sungguh. Kalau melakukan kesalahan dia berani mengakuinya. Bahkan kalau ia merasa kecewa dan sakit hati, dia tidak akan menyalahkan siapapun. Dia menyadari bahwa dirinya sendiri bertanggungjawab atas apapun yang dialaminya.

Pola komunikasi yang baik perlu diperhatikan antara orang tua dengan anak karena bagaimana pun juga, anak adalah harapan bangsa, anak merupakan penerus bangsa dan negara. Dengan demikian, perilaku anak yang buruk akan berdampak pula pada terbentuknya sumber daya bangsa yang berkepribadian buruk. Melalui pola komunikasi diharapkan para orang tua menyadari bahwa pentingnya menjaga perilaku positif anak. Dengan demikian selain membentuk perilaku positif anak yang sempurna, keharmonisan keluarga pun dapat diciptakan. Jadi, orang tua harus memahami dan membentuk perilaku positif anak dengan baik sehingga pada akhirnya 
anak dapat menjadi penerus bangsa yang berkepribadian yang matang.

\section{Simpulan}

Anak adalah amanah yang diberikan Allah Swt. yang harus diterima dengan segala potensi yang dimilikinya kepada orang tua, dan anak juga merupakan cikal bakal penerus kemajuan suatu bangsa dan agama. Untuk itulah penting sekali orang tua dalam memberikan pendidikan yang baik bagi anak agar menjadi pribadi yang tangguh, memiliki akhlak yang mulia dan cerdas dalam menyikapi perubahan zaman.

Keluarga memegang peranan penting dalam membentuk pribadi anak, karena keluarga merupakan institusi pertama yang secara langsung berinteraksi dengan anak, sehingga apa pun yang terjadi dalam keluarga akan berdampak terhadap anak.

Komunikasi keluarga adalah komunikasi yang terjadi dalam sebuah keluarga, yaitu cara seorang anggota keluarga untuk berinteraksi dengan anggota lainnya, sekaligus sebagai wadah dalam membentuk dan mengembangkan nilai-nilai yang dibutuhkan sebagai pegangan hidup.

Pola komunikasi yang baik pasti akan menciptakan pola asuh yang baik, dan pengasuhan anak akan berhasil dengan baik jika pola komunikasi yang tercipta dilandasi dengan cinta dan kasih sayang dengan memposisikan anak sebagai subjek yang harus dibina, dibimbing, dan dididik dan bukan sebagai objek semata.

\section{Daftar Pustaka}

A. W. Widjaja, Ilmu Komunikasi Pengantar Studi, Jakarta, Rineka Cipta, 2000.

Komunikasi dan Hubungan Masyarakat, Jakarta, Bumi Aksara, 2010. 
Charles H. Cooley dalam M. Amin Nurdin, Mengerti Sosiologi, Jakarta, UIN Jakarta Press, 2006.

Deddy Mulyana, Imu Komunikasi Suatu Pengantar, Bandung, Remaja Rosdakarya, 2000.

Dede Rahmat Hidayat, Teori dan Aplikasi Psikologi Kepribadian Dalam Konseling, Bogor, Ghalia Indonesia, 2011.

Hafied Cangara, Pengantar Imu Komunikasi, Jakarta, Raja Grafindo Persada, 2008.

J. Dwi Narwoko, Sosiologi Teks Pengantar dan Terapan, Jakarta, Prenada Media, 2004.

Jalaluddin Rakhmat, Psikologi Komunikasi, Bandung, Remaja Rosdakarya, 2011

Larry A. Samovar, Communication Between Cultures, Sixth Edition, USA; Thomson Higher Education, 2007.

Limbong, Hubungan Pola Komunikasi Keluarga dengan Perkembangan Kemampuan Sosialisasi dan Perkembangan Kemampuan Komunikasi Anak Usia Prasekolah pada Ibu Bekerja dan Ibu tidak Bekerja di Jakarta, tesis, Program Studi Psikologi UI, Jakarta, 1996.

M. Shochib, Pola Asuh Orang Tua dalam Membantu dan Anak Mengembangkan Disiplin, Jakarta, Rineke Cipta, 1998.

Ridwan Abdullah Sani, Muhammad Kadri, Pendidikan Karakter, Mengembangkan Karakter Anak Yang Islami, Jakarta, Bumi Aksara, 2016

Syaiful Rohim, Teori Komunikasi Perspektif, Ragam, \& Aplikasi, Jakarta, Rineka Cipta, 2009.

Syarkawi, Pembentukan Kepribadian Anak, Bumi Aksara, Jakarta, 2006.

Sunarto Kamanto, Pengantar Sosiologi, Jakarta, Lembaga Penerbit Fakultas Ekonomi Universitas Indonesia, 2004.

Syaiful Bahri Djamarah, Pola Komunikasi Orang Tua dan Anak dalam Keluarga, Jakarta, Rineka Cipta, 2004.

Theo Riyanto, Pembelajaran Sebagai Proses Bimbingan Pribadi, Jakarta, Grasindo, 2002

Willy F. Maramis, Albert A. Maramis, Ilmu Kedokteran Jiwa, Edisi 2, Jakarta, Airlangga University Press, 2009. 